\title{
Rethinking Education Environment: The Clinical Education Environment Framework
}

Submitted: $15-07-2018$

Accepted: 15-08-2018

Online: 28-09-2018

\author{
Nurhanis Syazni Roslan, Jamilah Al-Muhammady Mohammad, Mohd \\ Al-Aarifin Ismail, Anisa Ahmad, Muhamad Saiful Bahri Yusoff \\ Department of Medical Education, School of Medical Sciences, \\ Universiti Sains Malaysia, Kelantan, MALAYSIA
}

To cite this article: Roslan NS, Mohammad JA-M, Ismail MA-A, Ahmad A, Yusoff MSB. Rethinking education environment: the clinical education environment framework. Education in Medicine Journal. 2018;10(3):31-46. https://doi.org/10.21315/eimj2018.10.3.4

To link to this article: https://doi.org/10.21315/eimj2018.10.3.4

\section{ABSTRACT}

Educational environment is an important determinant of medical students' behaviour. It impacts their academic performance, motivation, and psychological well-being. Quantitative evidence have shown that there is a decrease in the positive perception of clinical medical students towards the educational environment. The primary focus on this study was to explore the clinical education environment through the lived experience of clinical medical students during medical training. Using hermeneutic phenomenology we aimed to interpret participants' experience of personal clinical learning journey through free text input. Thematic analysis was performed to analyse the written texts. Various measures were taken to enhance the trustworthiness of the findings. A total of 154 (74.8\%) fourth year students and $144(74.6 \%)$ final year students participated in the study. We identified six overarching themes of education environment in clinical setting that are personal development, teaching and learning, assessment for learning, facility, support and nurturing curriculum. The overlapping relationship of the themes is illustrated in the Clinical Education Environment Framework. While many themes were consistent with existing framework, our findings also proposed assessment as an important component to influence perception on education environment. The themes in this study finding conform to the definition of education environment which covers physical, social, and psychological aspects of students learning. Medical schools should take active measures to incorporate a nurturing education environment especially in clinical year where students struggle with the hidden curriculum.

Keywords: Education environment, Clinical environment, Students' perception Sciences, Universiti Sains Malaysia, 16150 Kubang Kerian, Kelantan, Malaysia | Email: msaiful_bahri@usm.my

\section{INTRODUCTION}

The medical school education environment has gained great attention in medical education literature for the past four decades (1). It has been shown as an important determinant that influences medical students' behaviours. Interestingly, the notion of education environment was initially conceptualised based on the dynamic of student stress and its impact on learning (1). However, with the recent understanding, education environment is now best defined as the physical, social, and psychological contexts in which students learn, and it is influenced by interactions with peers, staff, faculty, curriculum, facilities, and infrastructure $(2,3)$. 
A significant number of studies have shown education environment characteristics affect and influence students' cognitive, motivation, affect, and behaviour $(4,5)$. In medical school context, education environment have been shown to impact academic achievements, psychological health and satisfaction (6-9). Noteworthily, the medical school learning environment were perceived differently depending on the phase of medical training and generally perceived worst in clinical years. In addition, negative education environment are associated with burnout and reduced empathy of medical students (10). Growing evidence shows an alarming trend of declining positive perception among clinical medical students towards the clinical education environment during medical training. The findings were consistent across different educational settings suggesting a universal struggle shared by most of medical students (3,11-13). It was proposed that in clinical years, medical students are exposed to hidden curriculum, whereby they observed conflicting values in doctor-patient relationship, mistreatment to students and junior staffs and feeling unimportant in the workplace learning $(3,12,14)$. The significant influence of education environment can be explained by situated cognition theory that posits learning occurs in the social and physical environment context, and learning is situated in experience (15).

Although most agree that supportive educational environments are essential for effective medical education, an accurate assessment of educational environment quality has been challenging for educators and administrators due to the lack of educational environment framework (16). Despite that, numerous efforts have been made to develop education environment measurement scales, and now these scales are used as indicators of effective curriculum (17). These efforts have led to development of at least 12 scales to measure education environment in undergraduate medical curriculum (18).
One of the most widely used instruments is Dundee Ready Education Environment Measure (DREEM). It measures five aspects of education environment that are students' perception of learning, teaching, academic, atmosphere, and social elements (19). Nevertheless, given the limited validity evidence for the elements of existing educational environment tools, an educational environment framework may be needed as a guide to assess learners' perceptions of the relevant educational environment elements $(11,16,20)$. This paper reported the findings on desirable education environment as experienced by clinical medical students in a medical school.

\section{METHODOLOGY}

\section{Research Methodology}

We conducted a qualitative study using hermeneutic phenomenology approach to examine the learning experience of clinical year students during their medical training. Hermeneutic phenomenology has been described as a credible approach to identify and investigate issues based on individual or group lived experience by discovering something "meaningful" or "thematic" (21-23). The main interest of researchers was to explore the possible clinical learning environment construct by using students free text input that was collected as part of curriculum evaluation. The ethical approval was sought from the institution prior to the commencement of the study.

\section{The Participants}

We have selected the fourth and final year medical students from Universiti Sains Malaysia as the study participants. During the study duration, the medical school implemented a problem-based, integrated, community-oriented, and spiral medical curriculum (24). The medicine programme was divided into three phases. 
Phase 1 (Year 1) focused on basic sciences modules taught in organ-based systems. In Phase 2 (Year 2 and Year 3), the students were introduced to clinical clerkship with continuation of system-based teaching through problem-based learning. In Phase 3 (Year 4 and Year 5), the students underwent clinical phase where they were placed in various clinical disciplines.

\section{Data Collection Methods}

We invited all 206 fourth year and 193 final year students to participate in the study. Upon agreement to participate in this study, they were requested to write reflective inputs in a form based on an open and generic question, "What do you want from the school to improve your learning experience and environment?" The completed forms were immediately returned to the researcher. Each completed form was assigned with an identity code to maintain anonymity.

\section{Data Analysis}

All written texts were transcribed verbatim by a research assistant. Two researchers independently analysed each input using thematic analysis; a method to identify, analyse, and report themes across data. Thematic analysis has been proposed as an useful data analysis framework especially in an under-researched area or in situation with unknown participants view (25). Both researchers started with an open coding that were generated through inductive analysis. Then, each researcher combined their coding that are in coherence to form categories. In the final analysis, the researchers compared the coding and categories for agreements and formed overarching themes that represents the views from the participants. Analyst triangulation and peer scrutiny of findings were performed to ensure the trustworthiness of qualitative data and results.

\section{RESULTS}

In total, $154(74.8 \%)$ fourth year students and $144(74.6 \%)$ final year students returned the forms. We identified six overarching themes that are personal development, assessment for learning, teaching and learning strategies, facility, support, and curriculum.

\section{Theme 1: Personal Development}

Personal development occurs over the course of person life and it is particularly vital for medical students to become good doctors (26). Under this major theme, the participants highlighted several categories which are communication skills, motivation, social engagement, internationalisation, research exposure, students exchange, and career exposure. Although most of these subthemes were not an academic or assessment requirement, the participants proposed that the development of "person" is as essential as the "professional" development in becoming a doctor.

It's important to have motivational
programme to convince myself to
be a great doctor. (Y5:246)
We don't know much on what are
our possible future directions. We
should be introduced to various
paths. It is good to be exposed early,
so we have aims and ambitions.
(Y5:239)

Some participants also emphasised personal development as an important component in education environment so it will become an enabler for them to develop new skills.
We want research-oriented elective programme to brush our research skills, so we can contribute to the research university status and join the research community. (Y4:62)

These findings are consistent with a study on clinical year students by Seabrook that proposed students motivation and career development as part of education 
environment components (13). It also supports the findings in John Hopkins University School of Medicine which revealed "having opportunities to participate in outside interests beyond medicine" as one of the aspects that hugely influence students perception on education environment (27).

\section{Theme 2: Teaching and Learning Strategies}

Teaching and learning strategies refer to any activities that foster learning, including direct teaching and creation of associated instructional materials (28). The participants proposed several components under this theme that are accessible learning aids, learning skills empowerment, teaching skills, mentoring, supervision, up to date teaching material, nurturing learning environment. The participants highlighted the need to empower them with skills on evidence based medicine such as finding and appraising articles from journals.

How to read journal. How to find, read and appraise articles. We need to be equipped with these as there are so many journals on the internet. (Y4:66)

Several participants said that the educators have suggested many references to improve students learning experience but these were not freely accessible to them.

Free access to recommended reference by educators. (Y5:220)

Many participants emphasised on the need to institutionalised mentoring and supervision practice, rather than leaving it to the educators' personal style. These are consistent with findings that proposed relationship with supervisor as an important aspect of clinical education environment (29).

A regular meeting with mentor should be scheduled in academic calendar at least every three months, so we can have access to mentor. (Y5:290)
The participants also accentuated the importance of having nurturing education environment during teaching. These are consistent with the previous study in this institution that showed clinical year students' rating is lowest in DREEM items "the teachers are authoritarian", "the teachers get angry in teaching" and "the students irritate the teachers" as compared to the younger batches (11).

I call for all educators not to use
harsh words during teaching
session. We can be criticised
accordingly and scolded, but
rationally. (Y5:270)

The findings further support that teaching and learning aspects is an important determinants of education environment (2, 27) which is present in most instruments such as DREEM, Learning Environment Questionnaire (LEQ), and John Hopkins Learning Environment Scale (19, 30, 31).

\section{Theme 3: Assessment for Learning}

Assessment is any activity related to measuring learners' knowledge, skills, and attitudes (28). Although most of the instruments and other framework do not include assessment as one of the determinants for education environment, assessment that supports learning has emerged as the major theme in our study. The categories include having defined learning outcome, valid assessment, examination skills, feasible continuous assessment, feedback, and study leave. The participants called for assessment design that is not trivialised but instead informs their learning.

We need to redesign clinical year to be less logbook-oriented. (Y4:205)

Logbook oriented assessment made the students feel "robotic". Sometimes we do procedures without knowing the real principles and possibly overlooking the communication and human touch aspects. (Y4:322) 
The participants highlighted the importance of having feedback session especially in clinical setting where their learning is not as standardised as in pre-clinical year students. This is consistent with our previous findings that indicate feedback inadequacy in all clinical postings except for Paediatric, Orthopaedics, and Emergency Medicine (32).

We need feedback session after examination on how we can answer better so we will not repeat the mistakes in future. (Y4:667)

This supports the call for having programmatic assessment in which the assessment is robust whilst supporting the students growth (33).

\section{Theme 4: Facility}

Facility is basically referred to any building for instruction of registered learners in any educational institutions (34), and it is the most cited theme in this study. The participants emphasised on several categories that are accommodation, learning facility, on-call facility, sports facility, cafeteria, and transportation. They proposed that the facilities provided should match with the academic needs such as oncall or night rounds. This is paramount to ensure that safety is not compromised in the learning pursuit.

\begin{abstract}
All students should be given hostel rooms as it is very difficult to come for on-call or clerk at ward at night. (Y5:199)

We should have good environment where we don't have to worry on the accommodation, food quality and transportation to teaching sites. It will definitely optimise our learning process. (Y5:220)
\end{abstract}

This is consistent with other education environment instrument such as in DREEM ("My accommodation is pleasant") and categories in Hormozgan University framework (physical environment) $(19,35)$.
The participants also highlights that their learning facilities and accommodation should be equipped with good internet connection to support their learning.

We need to improve on internet
services. We need better speed
access, remove download
restrictions from useful learning
sites and access to chat platform
to allow for discussion among
students. (Y4:441)

\section{Theme 5: Support}

In the education context, support refers to a range of instructional methods, educational services, or educational resources provided to learners in the effort to help them accelerate their learning progress, catch up with their peers, meet learning standards, or generally succeed in school (36) - it also emerged as a major theme in this study. The participants proposed that support is essential to medical students and it is comprised of having mental health support, recognition, financial, administrative, and spiritual support.

It's good if we can have stress
management course. Like learning
how to deal with stress and feeling
content on being a doctor. (Y5:162)

We need enough breaks to rest. It's not enough to have just one week off for Eid or New Year. We need time to recuperate and to bring down the stress of being the final year students. (Y5:241)

The access to mental health support is paramount as growing data reveals poor mental health in clinical year students (37, 38). The clinical education environment may potentially break the peer support where the students are fragmented in different clinical rotations (3). It is also essential as students are exposed to professionalism dilemmas in workplace setting which has been reported to cause depressive symptoms, substance abuse, and cynicism (39). 
The participants also emphasised on having a supportive environment where students are given recognition on their effort and contribution to patient care. Based on self-determination theory, recognition is a powerful components in driving learning as the students will be driven by sense of autonomy and competence (40). This is against the common scenes in clinical learning where students are often humiliated, abused and not appreciated for their role in patient care $(12,39,41)$. In fact, recognition have been ranked in 3 out of 10 most important events that influence student perception in education environment ("Feeling that I contributed positively to patient care", "Having your efforts appreciated by patients and their families", and "Having your efforts appreciated by members of your clinical team") (27).

\section{Theme 6: Curriculum}

Curriculum refers to the designed, sequenced, and evaluated educational activities occurring at any training level (28). The participants highlighted several aspects of curriculum that are having integrated curriculum, early clinical exposure, nurturing curriculum structure, practical community project. This is consistent with the framework in LEQ which proposed curriculum as one of the determinants for education environment (31). Many participants emphasised on having an optimum clinical phase, where they have adequate duration in each posting to adjust to the learning experience.

I'd prefer earlier clinical exposure, like three years. It will allow us to be more exposed to procedures and life in the wards. Currently, I find transitioning in fourth year difficult and when you have just adapted, you are already in final year. Time is running out. (Y5:138)

The participants also stated the importance of having structured community projects to support their learning in clinical environment and prepare them for the internship. This can be explained by the authentic context of community project learning and more room for students in independence to handle patient at their level of competence (42).

We need community project in
rural or challenging area to prepare
us for working phase and to nurture
our volunteerism as medical
personnel. (Y5:156)

\section{The Clinical Education Environment Framework}

Based on the overlapping relationships of the six themes (i.e., personal development, teaching and learning, assessment for learning, facility, support, and curriculum) and 28 categories, a framework of desirable education environment in clinical year has been proposed as illustrated in the Figure 1. The proposed framework provides a basis for rectifying the current understanding on the clinical education environment based on experience of the clinical medical students. A table was provided to compare the proposed clinical education environment framework with other educational environment elements that were published since 1958 (please refer to Table 1).

\section{DISCUSSION}

The primary focus of this study was to explore the elements of desirable educational environment in a clinical setting based on medical students' experience went through the clinical medical training. The current study found that the clinical education environment can be categorised into six overarching themes that are personal development, teaching and learning, assessment for learning, facility, support, and curriculum. It is worthy to mention that the students are the best person to shed light on the elements of clinical education environment due to students are the "inhabitants" in the environment that determines their behaviour (18). Although 


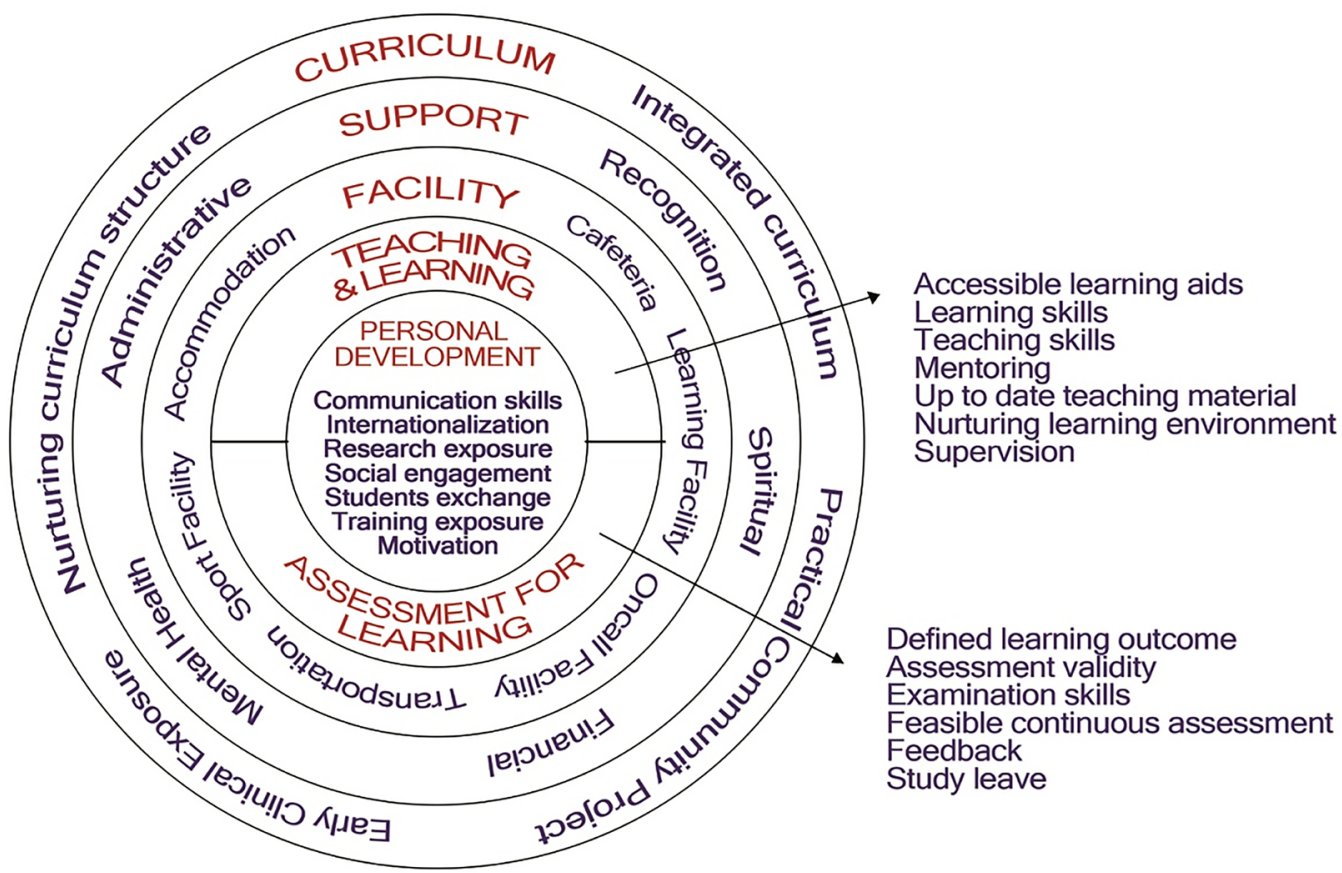

Figure 1: The Clinical Education Environment Framework.

this study reports findings from clinical medical students at a medical school, it is consistent with the elements of educational environment reported by many studies (summarised in Table 1). The elements of the clinical education framework are discussed in the subsequent paragraphs.

In this study, the elements related to personal development such as communication skills, motivation, social engagement, internationalisation, research exposure, students exchange, and career exposure were found to be repeatedly highlighted as important characteristics of clinical education environment. Interestingly, similar to this study, Fraser et al. has included the personal development dimension in the College and University Classroom Environment Inventory (43), in which this component is not clearly mentioned in other educational environment measurement tools (16). The most likely reason for this finding is due to lack of theoretical education environment framework and this concern has been also echoed by Schönrock-Adema et al. In this study, we argue that the personal development is essential element of educational environment to support student transition from the pre-clinical to clinical learning environment and later to the workplace as junior doctors.

Another important finding was that the elements related to teaching, learning and assessment such as learning aids, learning skills, teaching skills, mentoring, supervision, teaching material, defined learning outcome, valid assessment, examination skills, feasible continuous assessment, feedback, and study leave were found to be consistently mentioned by the medical students as important characteristics of clinical education environment. This finding broadly supports the work of other studies (summarised in Table 1) in this area linking the elements of teaching, learning and assessment with educational environment. This study confirms that teaching and learning elements are consistently associated with the educational environment. This study also provides evidence to demonstrate assessment as important as other components of educational environment, particularly in the clinical context. Although assessment is not included in major 
instruments used to measure educational environment such as in DREEM and LEQ $(19,31)$, it appears as a major theme in this study. We argue that assessment is an essential component associated with educational environment as it is a powerful drive in students learning (33, 55). Therefore, on top of teaching and learning elements, assessment should be considered into account when thinking about clinical education environment.

Table 1: Comparison of the clinical education environment constructs with other learning environment constructs $(1,19,43-54)$

\begin{tabular}{|c|c|c|}
\hline Instrument & Author & Measured constructs \\
\hline $\begin{array}{l}\text { The Clinical Education } \\
\text { Environment Framework } \\
\text { (Figure 1) }\end{array}$ & The present study & $\begin{array}{ll}\text { 1. } & \text { Personal development } \\
\text { 2. } & \text { Teaching and learning } \\
\text { 3. } & \text { Assessment for learning } \\
\text { 4. } & \text { Facility } \\
\text { 5. } & \text { Support } \\
\text { 6. } & \text { Curriculum }\end{array}$ \\
\hline College Characteristic Index & Pace \& Stern (1958) & $\begin{array}{ll}\text { 1. } & \text { Abasement } \\
\text { 2. } & \text { Achievement } \\
\text { 3. } & \text { Adaptiveness } \\
\text { 4. } & \text { Affiliation } \\
\text { 5. } & \text { Aggression - Blame avoidance } \\
\text { 6. } & \text { Change - Sameness } \\
\text { 7. } & \text { Conjunctivity - Disjunctivity } \\
\text { 8. } & \text { Counteraction } \\
\text { 9. } & \text { Deference } \\
\text { 10. } & \text { Dominance } \\
\text { 11. } & \text { Ego- Achievement } \\
\text { 12. } & \text { Emotionality - Placidity } \\
\text { 13. } & \text { Energy - Passivity } \\
\text { 14. } & \text { Exhibitionism } \\
\text { 15. } & \text { Fantasied achievement } \\
\text { 16. } & \text { Harm avoidance } \\
\text { 17. } & \text { Humanism } \\
\text { 18. } & \text { Impulsion - Deliberation } \\
\text { 19. } & \text { Narcissism } \\
\text { 20. } & \text { Nurturance } \\
\text { 21. } & \text { Objectivity - Projectivity } \\
\text { 22. } & \text { Order } \\
\text { 23. } & \text { Play } \\
\text { 24. } & \text { Pragmatism } \\
\text { 25. } & \text { Reflectiveness } \\
\text { 26. } & \text { Scientism } \\
\text { 27. } & \text { Sentience } \\
\text { 28. } & \text { Sex } \\
\text { 29. } & \text { Succorance - Autonomy } \\
\text { 30. } & \text { Understanding }\end{array}$ \\
\hline
\end{tabular}


Table 1: (Continued)

\begin{tabular}{|c|c|c|}
\hline Instrument & Author & Measured constructs \\
\hline $\begin{array}{l}\text { Medical School Environment } \\
\text { Inventory }\end{array}$ & Hutchins (1961) & $\begin{array}{l}\text { Faculty press scales: } \\
\text { 1. Affiliation } \\
\text { 2. } \text { Directiveness } \\
\text { 3. Enthusiasm } \\
\text { 4. Achievement } \\
\text { 5. } \text { Compliance } \\
\text { 6. Supportiveness } \\
\text { 7. Humanism } \\
\text { 8. Independence } \\
\text { 9. Pragmatism } \\
\text { Student press scales: } \\
\text { 1. Academic achievement } \\
\text { 2. Aggression } \\
\text { 3. Breadth of interests } \\
\text { 4. Competition } \\
\text { 5. Humanism } \\
\text { 6. Participation } \\
\text { 7. } \text { Reflectiveness } \\
\text { 8. Scientism } \\
\text { 9. Social conformity }\end{array}$ \\
\hline $\begin{array}{l}\text { Inventory of College } \\
\text { Characteristics }\end{array}$ & $\begin{array}{l}\text { Thistlethwaite (1962) } \\
\text { Nunnally, Thistlethwaite } \\
\text { (1963) }\end{array}$ & $\begin{array}{l}\text { Faculty: } \\
\text { 1. Systematised energy of faculty } \\
\text { 2. Toughness of faculty } \\
\text { 3. Availability of faculty to students } \\
\text { 4. Interestingness of lectures } \\
\text { 5. Faculty interest in arts and humanities } \\
\text { 6. Vocational emphasis } \\
\text { Student: } \\
\text { 1. Intellectual drive of students } \\
\text { 2. Personal appearance and manners } \\
\text { 3. Competition } \\
\text { 4. Science interest } \\
\text { 5. Pressure against scholarly activities } \\
\text { 6. Interest in visiting speakers }\end{array}$ \\
\hline $\begin{array}{l}\text { College and University } \\
\text { Environment Scales }\end{array}$ & Pace (1969) & $\begin{array}{l}\text { 1. Practicality } \\
\text { 2. Community } \\
\text { 3. Awareness } \\
\text { 4. Propriety } \\
\text { 5. Scholarship } \\
\text { 6. Campus morale } \\
\text { 7. Quality of teaching and faculty-student } \\
\text { relationships }\end{array}$ \\
\hline
\end{tabular}


Table 1: (Continued)

\begin{tabular}{|c|c|c|}
\hline Instrument & Author & Measured constructs \\
\hline $\begin{array}{l}\text { Learning Environment } \\
\text { Questionnaires }\end{array}$ & Rothman, Ayoade (1970) & $\begin{array}{l}\text { 1. Evaluative } \\
\text { 2. Academic enthusiasm } \\
\text { 3. Goal direction } \\
\text { 4. Authoritarianism } \\
\text { 5. Breadth of interest } \\
\text { 6. Student interaction } \\
\text { 7. Intellectual maturity }\end{array}$ \\
\hline $\begin{array}{l}\text { Classroom Environment } \\
\text { Scales }\end{array}$ & Moos, Trickett (1974) & $\begin{array}{ll}\text { 1. } & \text { Involvement } \\
\text { 2. } & \text { Affiliation } \\
\text { 3. } & \text { Teacher support } \\
\text { 4. } & \text { Task orientation } \\
\text { 5. } & \text { Order and organisation } \\
\text { 6. } & \text { Rule clarity }\end{array}$ \\
\hline $\begin{array}{l}\text { Medical School Learning } \\
\text { Environment Survey }\end{array}$ & Marshall (1978) & $\begin{array}{l}\text { 1. Flexibility } \\
\text { 2. Student-student interaction } \\
\text { 3. Emotional climate } \\
\text { 4. Supportiveness } \\
\text { 5. Meaningful learning experience } \\
\text { 6. } \\
\text { 7. } \\
\end{array}$ \\
\hline $\begin{array}{l}\text { Medical School Environment } \\
\text { Questionnaire }\end{array}$ & Wakeford (1981) & $\begin{array}{l}\text { Positive - Negative } \\
\text { 1. Friendly - Unfriendly } \\
\text { 2. Emphasising broad concepts - } \\
\text { Emphasising detailed knowledge } \\
\text { 3. Emphasising scholarship excellence - } \\
\text { Not aspiring philosophy of the first rate } \\
\text { 4. Emphasising ethical aspects - Not } \\
\text { emphasising ethical aspects } \\
\text { 5. Intensive (course) - Unhurried } \\
\text { 6. Vocationally oriented - Scientifically } \\
\text { biased } \\
\text { 7. Involving of students - Not involving of } \\
\text { students } \\
\text { 8. Flexible administratively - } \\
\text { Administratively inflexible } \\
\text { 9. Educationally facilitative, help student } \\
\text { learns - Making no special teaching } \\
\text { effort } \\
\text { 10. Emphasising extra-curricular activities - } \\
\text { No extra-curricular emphasis } \\
\text { 11. Written work important - Little written } \\
\text { work expected } \\
\text { 12. Enjoyable environment - Unenjoyable }\end{array}$ \\
\hline
\end{tabular}


Table 1: (Continued)

\begin{tabular}{|c|c|c|}
\hline Instrument & Author & Measured constructs \\
\hline $\begin{array}{l}\text { Learning Environment } \\
\text { Inventory }\end{array}$ & Fraser et al. (1982) & $\begin{array}{l}\text { 1. Satisfaction } \\
\text { 2. Challenge } \\
\text { 3. Cohesiveness } \\
\text { 4. Physical environment } \\
\text { 5. Democracy } \\
\text { 6. Goal direction } \\
\text { 7. Competition } \\
\text { 8. Formality } \\
\text { 9. Speed } \\
\text { 10. Diversity } \\
\text { 11. Apathy } \\
\text { 12. Favoritism } \\
\text { 13. Cliquishness } \\
\text { 14. Disorganisation } \\
\text { 15. Friction }\end{array}$ \\
\hline $\begin{array}{l}\text { College and University } \\
\text { Classroom Environment } \\
\text { Inventory }\end{array}$ & Fraser et al. (1986) & $\begin{array}{l}\text { Relationship dimension: } \\
\text { 1. Personalisation } \\
\text { 2. Involvement } \\
\text { 3. Student cohesiveness } \\
\text { 4. Satisfaction } \\
\text { Personal development dimension: } \\
\text { 1. Task orientation } \\
\text { System maintenance and system change } \\
\text { dimension: } \\
\text { 1. Innovation } \\
\text { 2. Individualisation }\end{array}$ \\
\hline $\begin{array}{l}\text { Dundee Ready Education } \\
\text { Environment Measure }\end{array}$ & Roff et al. (1997) & $\begin{array}{l}\text { 1. Students' perception of teaching } \\
\text { 2. Students' perceptions of teachers } \\
\text { 3. Students' academic self-perceptions } \\
\text { 4. Students' perceptions of atmosphere } \\
\text { 5. Student's social self-perceptions }\end{array}$ \\
\hline $\begin{array}{l}\text { Postgraduate Hospital } \\
\text { Educational Environment } \\
\text { Measure }\end{array}$ & Roff et al. (2005) & $\begin{array}{l}\text { 1. Perceptions of teaching } \\
\text { 2. Perceptions of teachers } \\
\text { 3. Academic self-perceptions } \\
\text { 4. Perceptions of atmosphere } \\
\text { 5. Social self-perceptions }\end{array}$ \\
\hline $\begin{array}{l}\text { Practice-Based Educational } \\
\text { Environment Measure }\end{array}$ & Mulrooney (2005) & $\begin{array}{l}\text { 1. The practice job } \\
\text { 2. GP trainer } \\
\text { 3. Teaching and learning } \\
\text { 4. Interaction with other health } \\
\text { professionals }\end{array}$ \\
\hline
\end{tabular}


An obvious finding to emerge from the analysis was that the elements related to learning facility and support such as accommodation with good internet access, learning facility, on-call facility, sports facility, cafeteria, transportation, mental health support, recognition of student contribution to patient care, financial, administrative, and spiritual support were repeatedly echoed by the medical students as important characteristics of clinical education environment. In accordance with the present results, previous studies have demonstrated that the learning facility is essential element of educational environment and it can be seen in most of educational environment measurement tools $(16,19,31,42,44)$. Our framework offers a more complete perspective to educational environment as it proposes the learning support as a desirable aspect. This is aligned with the definition of educational environment which encompasses physical, social, and psychological contexts of students learning (3). In line with the current education trends of evidence-based medicine, flexible, and online learning (2), the framework also includes learning facility and support such as internet access to enhance the students learning. Our findings also emphasises on the nurturing education environment as manifested by many categories across the framework such as recognition of student contribution to patient care and access to mental health support. The learning facility and support are crucial elements of educational environment to support students' readiness and preparedness to reflect and develop their professional identity as tomorrow's doctors.

The most relevant finding was that several elements related to curriculum such as integrated curriculum, early clinical exposure, nurturing curriculum structure, and community-oriented curriculum were repeatedly considered by medical students as important characteristics of clinical education environment. This study produced results which corroborate the findings of a great deal of the previous work in learning environment (summarised in Table 1). Though a curriculum covers the teaching, learning, and assessment aspects, yet in this framework the curriculum elements are more inclined towards its structure, system, and strategy. Logically, different curriculum structure, system, and strategy will result in different quality of learning environment. This view is supported by Genn statement as he suggests, "The environment of the medical is notable, not only because it derives from and is a manifestation of the curriculum, but because the environment is a determinant, of the behaviour of the medical school's students and teachers" (2). An example to support this view, several studies found that the levels and sources of distress experienced by medical students are different depending on the type of curriculum (56-57) and the phase of medical training (36). Perhaps, given the consistent findings on the clinical year students' struggle, medical schools should strive to design the medical curriculum that support desirable learning environment for medical students to grow as competent doctors.

Several limitations of the study include the use of single institution in the data collection and the use of single qualitative methods that limit its transferability to other contexts. Although students perception has been proposed as the most important determinant in education environment $(18,58)$, the analysis from education environment models have revealed that there is a complex interplay between individual and institutional-level factors which influence their perceptions (58). The utilised method in this study might reveal less of the institutional-level factors, which might be better appreciated by the faculty rather than the students.

Despite the limitations, the clinical education environment framework provides a guide for educators and administrators to evaluate their education environment. The elements related to the personal 
development can be used to inform the blueprint of personal and professional development programmes in clinical year students. Meanwhile the elements related to the teaching, learning, assessment, and curriculum may form the focus of faculty development programme. Even more, the elements related to learning facility and support can be used to inform the focus of learning resource development by medical schools and universities. Nevertheless, more research is required to provide better understanding and interpretation on the interrelations of the themes and categories in the proposed framework.

\section{CONCLUSION}

Medical students' perceptions on desirable education environment in clinical year setting include the component of personal development, teaching and learning, assessment for learning, facility, support, and nurturing curriculum. The components conform to the definition of education environment which covers physical, social, and psychological aspects of students learning. Given the nature of clinical learning environment that could have exposed medical students to hidden curriculum, medical school should take an active measure to address this aspect.

\section{REFERENCES}

1. Marshall RE. Measuring the medical school learning environment. J Med Educ. 1978;53(2):98-104. https://doi.org/ 10.1097/00001888-197802000-00003

2. Genn JM. AMEE medical education guide no. 23 (Part 1): Curriculum, environment, climate, quality and change in medical education - a unifying perspective. Med Teach. 2001;23(4):337-44. https://doi.org/ $10.1080 / 01421590120063330$
3. Dunham L, Dekhtyar M, Gruener G, CichoskiKelly E, Deitz J, Elliott D, et al. Medical student perceptions of the learning environment in medical school change as students transition to clinical training in undergraduate medical school. Teach Learn Med. 2017;29(4):383-91. https://doi.org/10. 1080/10401334.2017.1297712

4. Karabenick SA. Perceived achievement goal structure and college student help seeking. J Educ Psychol. 2004;96(3):569-81. https:// doi.org/10.1037/0022-0663.96.3.569

5. Lüdtke O, Robitzsch A, Trautwein U, Kunter M. Assessing the impact of learning environments: how to use student ratings of classroom or school characteristics in multilevel modeling. Contemp Educ Psychol. 2009;34(2):120-31. https://doi.org/ 10.1016/j.cedpsych.2008.12.001

6. Mayya SS, Roff S. Students' perceptions of educational environment: a comparison of academic achievers and under-achievers at Kasturba Medical College, India. Educ Heal. 2004;17(3):280-91. https://doi. org/10.1080/13576280400002445

7. Lizzio A, Wilson K, Simons R. University students' perceptions of the learning environment and academic outcomes: implications for theory and practice. Stud High Educ. 2002;27(1):37-41. https://doi. org/10.1080/03075070120099359

8. Wayne SJ, Fortner SA, Kitzes JA, Timm C, Kalishman S. Cause or effect? The relationship between student perception of the medical school learning environment and academic performance on USMLE Step 1. Med Teach. 2013;35(5):376-80. https://doi. org/10.3109/0142159X.2013.769678

9. Yusoff MSB, Arifin WN. Educational environment and psychological distress of medical students: the role of a deep learning approach. J Taibah Univ Med Sci. 2015;10(4):411-8. https://doi.org/10.1016/j. jtumed.2015.08.005 
10. Brazeau CMLR, Schroeder R, Rovi S, Boyd L. Relationships between medical student burnout, empathy, and professionalism climate. Acad Med. 2010;85(10 SUPPL.):33-6. https://doi.org/10.1097/ ACM.0b013e3181ed4c47

11. Yusoff MSB, Jaa'far R, Arzuman H, Arifin WN, Mat Pa MN. Perceptions of medical students regarding educational climate at different phases of medical training in a Malaysian medical school. Educ Med J. 2013;5(3):30-41. https://doi.org/10.5959/ eimj.v5i3.146

12. McKee A, Markless S. Using action learning sets to support students managing transition into the clinical learning environment in a UK medical school. Action Learn Res Pract. 2017;14(3):275-85. https://doi.org/10.1080/ 14767333.2017 .1360933

13. Seabrook M. Clinical students' initial reports of the educational climate in a single medical school. Med Educ. 2004;38:659-69. https:// doi.org/10.1111/j.1365-2929.2004.01823.x

14. Gan R, Snell L. When the learning environment is suboptimal: exploring medical students' perceptions of "mistreatment." Acad Med. 2014;89(4):608-17. https://doi.org/10.1097/ ACM.0000000000000172

15. Durning SJ, Artino AR. Situativity theory: a perspective on how participants and the environment can interact: AMEE Guide no. 52. Med Teach. 2011;33(3):188-99. https:// doi.org/10.3109/0142159X.2011.550965

16. Schönrock-Adema J, Bouwkamp-Timmer T, van Hell EA, Cohen-Schotanus J. Key elements in assessing the educational environment: where is the theory? Adv Heal Sci Educ. 2012;17(5):727-42. https://doi. org/10.1007/s10459-011-9346-8

17. Abraham R, Ramnarayan K, Vinod P, Torke S. Students' perceptions of learning environment in an Indian medical school. BMC Med Educ. 2008;8:20. https://doi. org/10.1186/1472-6920-8-20
18. Soemantri D, Herrera C, Riquelme A. Measuring the educational environment in health professions studies: a systematic review. Med Teach. 2010;32(12):947-52. https://doi.org/10.3109/01421591003686229

19. Roff S, McAleer S, Harden RM, AlQahtani M, Ahmed AU, Deza $\mathrm{H}$, et al. Development and validation of the dundee ready education environment measurement (DREEM). Med Teach. 1997;19(4):295-9. https://doi.org/10.3109/01421599709034208

20. Yusoff MSB. The Dundee ready educational environment measure: a confirmatory factor analysis in a sample of Malaysian medical students. Int J Humanit Soc Sci. 2012;2(16):313-21.

21. Ajjawi R, Higgs J. Using hermeneutic phenomenology to investigate how experienced practitioners learn to communicate clinical reasoning. Qual Rep. 2007;12(4):612-38.

22. Sloan A, Bowe B, Bowe B. Phenomenology and hermeneutic phenomenology: the philosophy, the methodologies and using hermeneutic phenomenology to investigate lecturers' experiences of curriculum design phenomenology and hermeneutic. Eng Innov. 2014;48(3):1291-303. https://doi. org/10.1007/s11135-013-9835-3

23. van Manen M. Researching lived experience: human science for an action sensitive pedagogy. 2nd ed. London, Ontario, Canada: Althouse Press; 1997.

24. Zabidi-Hussin ZAMH, Abdul Rahim AF. Medical education in Universiti Sains Malaysia. Med J Malaysia. 2003;57(Suppl E):8-12.

25. Braun V, Clarke V. Using thematic analysis in psychology. Qual Res Psychol. 2006;3(2):77-101. https://doi.org/10.1191/ 1478088706qp063oa 
26. Nor MZM, Yusoff MSB, Ismail MA-A. The patterns of profesional identity development among medical graduates of SPICES curriculum. Educ Med J. 2017;9(4):51-61. https://doi.org/10.21315/eimj2017.9.4.6

27. Shochet RB, Colbert-Getz JM, Levine $\mathrm{RB}$, Wright SM. Gauging events that influence students' perceptions of the medical school learning environment: findings from one institution. Acad Med. 2013;88(2):246-52. https://doi.org/10.1097/ ACM.0b013e31827bfa 14

28. Yusoff MSB, Alias AK, Salleh F. Scholarship of teaching and learning in higher education: an assessment framework. Educ Med J. 2013;5(2):1-5.

29. Bos E, Alinaghizadeh H, Saarikoski M, Kaila P. Validating the "clinical learning environment, supervision and nurse teacher" CLES+ $\mathrm{T}$ instrument in primary healthcare settings using confirmatory factor analysis. J Clin Nurs. 2012;21(11-12):1785-8. https:// doi.org/10.1111/j.1365-2702.2011.04030.x

30. Sengupta P, Sharma A, Das N. Perception of learning environment among undergraduate medical students in two different medical schools through DREEM and JHLES questionnaire. J Clin Diagnostic Res. 2017;11(2):JC01-4. https://doi.org/ 10.7860/JCDR/2017/23810.9248

31. Moore-West M, Harrington DL, Mennin SP, Kaufman A, Skipper BJ. Distress and attitudes toward the learning environment: effects of a curriculum innovation. Teach Learn Med. 1989;1(3):151-7. https://doi. org/10.1080/10401338909539400

32. Ahmad A, Roslan NS, Mohammad JA-M, Yusoff MSB. Medical graduates' perception on the quality of clinical education. Educ Med J. 2015;7(December):52-9.

33. Van Der Vleuten CP, Schuwirth LW, Driessen EW, Dijkstra J. A model for programmatic assessment fit for purpose. Med Teach. 2012;34(3):205-14. https://doi. org/10.3109/0142159X.2012.652239
34. The State of Virginia. A dictionary of legal, industry-specific, and uncommon terms. Code of Virginia. 2012 [cited 21 July 2018]. Available from: https://definedterm.com/a/ entity/the_state_of_virginia

35. Aghamolaei T, Shirazi M, Dadgaran I, Shahsavari H, Ghanbarnejad A. Health students' expectations of the ideal educational environment: a qualitative research. J Adv Med Educ Prof. 2014;2(44):151-7.

36. Great Schools Partnership. Academic Support. The Glossary of Education Reform. 2013 [cited 21 July 2018]. Available from: https://www.edglossary.org/

37. Chin ARW, Yusoff MSB, Wong MS, Lee YY. Prevalence of burnout among Universiti Sains Malaysia medical students. Educ Med J. 2016;8(September):61-74. https://doi. org/10.5959/eimj.v8i3.454

38. Yusoff MSB, Abdul Rahim AF, Yaacob MJ. Prevalence and sources of stress among Universiti Sains Malaysia medical students. Malaysia J Med Sci. 2010;17(1):30-7.

39. Rees CE, Monrouxe LV. Learners' wellbeing "a morning since eight of just pure grill": a multischool qualitative study of student abuse. Academic Medicine: Journal of The Association of American Medical Colleges. 2011;86(11):1374-82.

40. Schumacher DJ, Englander R, Carraccio C. Developing the master learner: applying learning theory to the learner, the teacher, and the learning environment. Acad Med. 2013;88(11):1635-45. https://doi.org/10. 1097/ACM.0b013e3182a6e8f8

41. Benbassat J. Undesirable features of the medical learning environment: a narrative review of the literature. Adv Heal Sci Educ. 2013;18(3):527-36. https://doi.org/10.1007/ s10459-012-9389-5 
42. Salminen H, Öhman E, Stenfors-Hayes T. Medical students' feedback regarding their clinical learning environment in primary healthcare: a qualitative study. BMC Med Educ. 2016;16(1):1-7. https://doi. org/10.1186/s12909-016-0837-4

43. Fraser BJ, Treagust DF, Dennis NC. Development of an instrument for assessing classroom psychosocial environment at universities and colleges. Stud High Educ. 1986;11(1):43-54. https://doi.org/10.1080/0 3075078612331378451

44. Pace CR, Stern G. An approach to the measurement of the psychological characteristics of learning environments. J Educ Psychol. 1958;49(6):269-77. https:// doi.org/10.1037/h0047828

45. Hutchins EB. The 1960 medical school graduate: his perception of his faculty, peers and environment. J Med Educ. 1961;36(4):322-9.

46. Thistlethwaite DL. Fields of study and development of motivation to seek advanced training. J Educ Psychol. 1962;53(2):53-64. http://doi.org/10.1037/h0040200

47. Nunnally J, Thistlethwaite DL. Factored scales for measuring characteristics of college environment. Educ Psychol Meas. 1963;XXIII(2):239-48. https://doi.org/10. $1177 / 001316446302300202$

48. Pace CR. College and university environment scales (CUES). 2nd ed. Technical manual. Princeton: Educational Testing Service; 1969.

49. Rothman A, Ayoade F. The development of a learning environment: a questionnaire for use in curriculum evaluation. J Med Educ. 1970;45(October):754-9. https://doi. org/10.1097/00001888-197010000-00006

50. Moos R, Tricket E. Manual:classroom environment scale. Palo Alto: Consulting Psychologists Press; 1974.
51. Wakeford RE. Students' perception of the medical school learning environment: a pilot study into some differences and similarities between clinical schools in the U.K. Assess Eval High Educ. 1981;6(3):206-17. https:// doi.org/10.1080/0260293810060303

52. Fraser BJ, Andersong J, Wallberhg J. Assessment of learning environments: manual for the learning environment inventory (LEI) and my class inventory. Bentley: Western Australia Institute of Technology; 1982.

53. Roff S, McAleer S, Skinner A. Development and validation of an instrument to measure the postgraduate clinical learning and teaching educational environment for hospital-based junior doctors in the UK. Med Teach. 2005;27(4):326-31. https://doi. org/10.1080/01421590500150874

54. Mulrooney A. Development of an instrument to measure the practice vocational training environment in Ireland. Med Teach. 2005;27(4):338-42. https://doi. org/10.1080/01421590500150809

55. Cleland J, Cilliers F, van Schalkwyk S. The learning environment in remediation: a review. Clin Teach. 2018;15(1):13-8. https://doi.org/10.1111/tct.12739

56. Yen Yee L, Yusoff MSB. Prevalence and sources of stress among medical students in Universiti Sains Malaysia and Universiteit Maastricht. Educ Med J. 2013;5(4):34-41. https://doi.org/10.5959/eimj.v5i4.190

57. Yusoff MSB, Yee LY, Wei LH, Meng LH, Bin LX, Siong TC, et al. A study on stress, stressors and coping strategies among Malaysian medical students. Int $\mathrm{J}$ Students' Res. 2011;1(2):45-50. https://doi. org/10.5549/IJSR.1.2.45-50

58. Gruppen LD, Brent Stansfeld R. Individual and institutional components of the medical school educational environment. Acad Med. 2016;91(11):S53-7. https://doi.org/10.1097/ ACM.0000000000001361 